\title{
NIEZATARTE PRĘGI
}

\section{ROMAN CHYMKOWSKI, NIETOŻSAMOŚCI. TILLION, FANON, BOURDIEU, DERRIDA I DYLEMATY DEKOLONIZACJI}

Marcin Darmas

Uniwersytet Warszawski

Jakaż dziwna koincydencja! Z jednej strony Państwowy Instytut Wydawniczy reaktywuje prestiżową serię „Plus Minus Nieskończoność” esejem Pascala Brucknera Tyrania skruchy. Rozważania na temat samobiczowania Zachodu (Bruckner 2019), a $\mathrm{z}$ drugiej wydawnictwo Campidoglio publikuje Nietożsamości. Tillion, Fanon, Bourdieu, Derrida i dylematy dekolonizacji Romana Chymkowskiego. Można odnieść wrażenie, że to nie przypadek i że pod wieloma względami obie publikacje prowadzą ze sobą zażartą polemikę. Jej przedmiotem - Algieria. Właściwie, stosunek Francji do byłej kolonii, rozrachunek ze wstydliwą przeszłością, wojną domową i procesem dekolonizacji. Dla Brucknera pręgi winny dawno zniknąć, bez tego ani Francja, ani Algieria nie pójdą do przodu; dla Chymkowskiego bez nich nie sposób zrozumieć współczesnej humanistyki francuskiej. Wszystko wskazuje na to, że kwestia algierska, a może szerzej - kwestia dekolonizacji - są aktualne, czekają na rozstrzygnięcie...

Bruckner zdaje się mówić: zostawmy już skruchę za krzywdy francuskiego kolonializmu. Przepraszanie to według Brucknera nadinterpretacja myśli chrześcijańskiej przez potomków pokolenia '68, jej wynaturzenie; jeszcze inaczej, to zafiksowanie perwersyjnego konfesjonału - stworzonego bez możliwości rozgrzeszenia. Co gorsza, przepraszanie przeobraziło się w walutę: za cenę tytułowej skruchy zdobywa się nowe rynki, które niegdyś podbijało się żelazem. Tak oto dokonuje się nowoczesna rekonkwi- 
sta za cenę własnej godności i zaprzeczenia tożsamości historycznej. Doprowadza to w ostateczności nie tylko do wstydu za siebie, ale również do zaprzeczania idei samego Zachodu - antioccidentalisme. Esej Pascala Brucknera jest czymś w rodzaju nowej wariacji na temat zdrady klerków. Został uruchomiony nowy handel intelektualny: klerkowie zostali wyznaczeni do jego utrzymania, jak niegdyś strażnicy ognia, wydają pozwolenie na myślenie, na mówienie...

Roman Chymkowski lokuje się w zgoła innym kręgu myślenia. Mówi: nie zdołamy zrozumieć Germaine Tillion, Frantza Fanona, Pierre’a Bourdieu, Jacques’a Derridy, ba!, całej współczesnej francuskiej humanistyki bez uwzględnienia rozrachunków z kolonialną przeszłością, a zwłaszcza bez wątków algierskich. Nawiasem mówiąc, nie sposób zrozumieć systemowego wyboru Chymkowskiego: dlaczego na liście intelektualistów znalazł się Fanon, marksistowski radykał namawiający do przemocy, a nie znalazł się portret najbardziej uprawniony i etycznie relewantny - Alberta Camusa? Każdy z wymienionych tuzów, mniej lub bardziej, osobiście, rodowodowo, związany był z Algieria. I wszyscy, z różną intensywnością i z różnych pozycji, występowali przeciwko polityce Francji, wzmacniając utrzymująca się po dziś dzień, według Brucknera, logikę skruchy. Wprost zastanawiajace, do jakiego stopnia sprawa kolonialna, niegdyś dyskutowana jedynie na paryskich salonach, objawiła swoją moc dekretującą dopiero w wieku XXI (vide ustawy Taubiry). Chymkowski w swoich rozważaniach dobrze pokazuje, jak kontrowersyjne były poglądy takich intelektualistów jak Tillion czy Bourdieu, gdy powstawały, by stać się w końcu obowiązująca doksą. Byli oni koryfeuszami przemiany myślenia kolonialnego. Poprzez nich Francja podjęła autorefleksję nad „wstydliwą przeszłością” i usankcjonowała prawem swoje przewiny.

Chymkowskiemu w dużej mierze, obok malowania portretów myślicieli i ich uwikłania w sprawy algierskie, chodzi o wskazanie momentu kresu myśli europocentrycznej w humanistyce francuskiej. Nie ulega wszak wątpliwości, że prezentowani przez Chymkowskiego intelektualiści zainicjowali nowe myślenie o peryferiach jako doświadczeniu konstytutywnym. Co więcej, introspekcja i dekonstrukcja, wyrastające bezpośrednio z logiki kultury indywidualizmu, stały się conditio sine qua non refleksji filozoficznej. Chymkowskiego nie interesuje przynależność do dyscyplin, nie chodzi mu nawet o „rekonstrukcję faktów z życia poszczególnych autorów”, lecz o „ponowną lekturę ich dzieł [...] w kontekście uwikłania w dwudziestowieczną historię Algierii”" (Chymkowski 2019: 25). Ergo - skrzyżować spojrzenia, jak mawiają Francuzi, croiser les regards. 
Nie sposób w pełni odmalować ich portretów intelektualnych bez dawnej kolonii, bez zrozumienia ich stosunku do kwestii algierskiej. Chymkowski pisze wprost: ,chciałbym [...] sprawić, by kolonialne uwikłanie myśli autorów tu omawianych zostało nazwane wprost i odpowiednio docenione w kontekście całokształtu ich intelektualnych dokonań” (tamże: 27). W dalszej części rozważań zamykających przedmowę mówi o kryzysie nauk humanistycznych, by intrygująco zakończyć stwierdzeniem: „Poszukując w pracach Bourdieu czy Derridy dróg, którymi może podążać zachodnia myśl krytyczna, natrafiamy na świadectwa tego, że nie jest ona, a może nawet nigdy nie była «zachodnia» w sensie, jaki temu słowu nadaje język tożsamości, i że właściwie jej nietożsamość jest warunkiem pozytywności” (tamże: 27). Myśl ta nie znalazła swojego rozwinięcia na stronach Nietożsamości - a szkoda...

Chymkowski uczciwie wskazuje różne paradoksy, między innymi ten: „z punktu widzenia nauki wyprawa badawcza Thérèse Rivière i Germaine Tillion była paradoksalna $-z$ jednej strony została przygotowana przez grono wybitnych uczonych epoki i, czego bynajmniej nikt nie ukrywał, wpisywała się w oficjalną politykę państwa francuskiego wobec kolonii, z drugiej jednak stanowiła bardzo śmiały eksperyment, który niekoniecznie musiał zakończyć się sukcesem: oto bowiem wysyłano na ważną z różnych powodów misję osoby praktycznie bez doświadczenia i dorobku naukowego" (tamże: 33). Etnografowie, socjolodzy i antropologowie mieli za zadanie dostarczyć odpowiedniej wiedzy centrali, by mogła uydatniej sprawować władzę nad swoją afrykańska prowincją.

Wymyślając mnóstwo fint i forteli Tillion i Bourdieu zdobyli w dawnej kolonii etnograficzne szlify, nauczyli się technik obserwacji uczestniczącej, ale również dojrzewali politycznie i ideologicznie. Z pewnością, bez Algierii francuskiej, w sensie jakobińskim, czyli Francji de facto represyjnej, wyjście z naukowej i politycznej adolescencji nie byłoby dla nich możliwe. Dla Tillion badania w północnej Afryce stały się dodatkowo przebudzeniem etycznym, zrozumiała wówczas ciążącą na naukowcu odpowiedzialność za badaną społeczność oraz odpowiedzialność ,jako gotowość niesienia pomocy w osiagnięciu tych wartości, w które autorka wierzy i dzieli tę wiarę z wieloma innymi współczesnymi jej francuskimi intelektualistami” (tamże: 40). Bruckner powiedziałby, że to założenie ontologii badań in bona fide doprowadziło do nieszczęść w północnej Afryce, nie była ona bowiem gotowa ani na niepodległość, ani na suwerenność. W dramatycznych słowach podkreślał niegotowość Algierii do autonomii prezydent de Gaulle podczas konferencji prasowej 5 września 1961 r. Grosso modo, generał 
przestrzegał, że Francja poradzi sobie ekonomicznie i ustrojowo bez Algierii. I zadawal pytanie - czy poradzi sobie Algieria? Przestrzegał przed niepokojami społecznymi, myślami rewanżystowskimi i niepewnością co do przyszłego ustroju kraju1. Obecne losy Algierii dobitnie pokazuja, że de Gaulle się nie mylił.

Najtrudniejsze fragmenty Nietȯ̇samości to te opisujące Frantza Fanona. Postać $z$ jednej strony piękną i szlachetną, pomagającą chorym umysłowo, z drugiej strony radykalną i nawołująca do przemocy wobec francuskiego oprawcy. Wspierany przez Jean-Paula Sartre’a nawoływał współbraci w niewoli do makabrycznych czynów. Sartre zresztą zawarł skrajnie rewanżystowskie myśli w posłowiu do opus magnum Fanona Wyklety lud ziemi. Warto je przytoczyć: „ślady gwałtu może zetrzeć jedynie gwałt. Mieszkaniec kolonii leczy się z kolonialnej nerwicy, wypędzając kolonistę siłą" (Sartre 1994: 227). Jakże daleko jesteśmy od myśli innego Francuza, Victora Hugo, który mówił, że krwi nie zmyje inna krew - bo krew zmyć moga tylko Łzy...

W rozdziale dotyczącym Pierre'a Bourdieu Chymkowski wiernie rekonstruuje hochsztaplerstwa Francuza związane z badaniem Kabylów. Powołuje się na badania Izabeli Wagner, która wskazała, że socjolog dość obficie korzystał z obserwacji i prac swojego współpracownika, Abdelmaleka Rayada, jednocześnie umniejszając jego wkład. Owe pominięcia, zdaje się, dość często były przezeń praktykowane. Bourdieu potrafił akceptować jedynie apologetykę własnej osoby; Chymkowski przywołuje Adama Podgóreckiego, który zaliczał Bourdieu do myślicieli „instrumentalno-narcystycznych" (Chymkowski 2019: 107). Tak czy inaczej, rozstrzygnięcia, które nakarmiły myśl Bourdiańska, zostały zainicjowane w Algierii. Tam autor Dystynkecji zrozumiał, że „u podstaw nie tylko kolonialnego, ale wręcz każdego prawno-politycznego porząadku leży przemoc" (tamże: 135).

I na końcu - „nietożsamość” Derridy, Franko-Maghrebczyka, o zaburzonej tożsamości i zdekonstruowanym obywatelstwie. Nie brakuje tu aluzji do Francji Vichy, do ustaw antyżydowskich, pamięci nie do końca rozliczonej w przekonaniu filozofa: „Algierskie pochodzenie i związane z nim traumy czyniły Derridę szczególnie wyczulonym na dramatyczne doświadczenie historyczne innych narodów" - pisze Chymkowski (tamże: 177). Niemniej przytaczane tu i ówdzie refleksje Derridy oddają hołd, bądź co bądź, wielkości kultury francuskiej, możliwościom, jakie mu dała. A właściwie - dzięki możliwościom języka, w którym wedle jego własnych słów, zamieszkał pomimo „nostalgierii” zapisanej w jego genotypie...

1 Zob. Nouschi 2013: 163-170. 
Bruckner pisze: „Europa dużo szybciej zakończyła żałobę po utracie kolonii niż ich mieszkańcy po utracie Europy. Ponieważ ta ostatnia nie pogrążyła się po dekolonizacji w konwulsjach fizycznych i duchowych co zaprzecza tezie, jakoby zawdzięczała swe bogactwo rabunkowi, na nierównoprawnych zasadach, Południa - można jedynie bez ustanku podkreślać jej perwersyjny charakter" (Bruckner 2019: 23). Chymkowski opisuje stopniowo odchodzącą w niełasce familię myślicieli, zanurzonych po uszy w marksistowskich reinterpretacjach Alexandra Kojève’a, która poniosła dotkliwą klęskę. Niewielu szaleńców stara się dziś negować nędzę francuskiego kolonializmu. A jeszcze mniej ma odwagę pokazywać jego blaski, lista mogłaby się okazać kłopotliwie długa: szeroko zakrojona alfabetyzacja, eksport republikańskiej szkoły (niedawno słynny dziennikarz Pierre Bénichou wyznał na falach Europe 1, że liceum w Oranie o głowę przewyższało w latach 50. większość szkół paryskich), prawo cywilne, laickość, infrastruktura... Intelektualiści opisywani przez Chymkowskiego, rzecz jasna nieświadomie, in bona fide, uruchomili siły, które trudno zatrzymać. Chymkowski zapomina określić naturę ich orientacji ideologicznej, polega ona na szukaniu win ciemiężców. Łatwo tę logikę zainicjować, trudniejzakończyć. Ale to być może temat do innych rozważań...

Nie ulega jednak wątpliwości, że dzisiejsza Algieria znajduje się daleko od etycznych wyobrażeń Derridy et consortes. Nie stała się ani całkowicie wolna, ani całkowicie demokratyczna. Na miejsce dawnych kolonizatorów przyszli Ajatollahowie, o wiele groźniejsi niż ich poprzednicy. Gwiżdżą na wolność i swobodę, Marksa nie czytali, nienawidzą Republiki, a na słowo „emancypacja” w najlepszym razie parskaja śmiechem, a w najgorszym biorą do ręki kamień.

Bibliografia:

/// Bruckner P. 2019. Tyrania skruchy. Rozważania na temat samobiczowania Zachodu, tłum. A. Szeptycki, PIW.

/// Chymkowski R. 2019. Nietożsamości. Tillion, Fanon, Bourdieu, Derrida i dylematy dekolonizacji, Campidoglio.

/// Fanon F. 1985. Wyklety lud riemi, tłum. H. Ilgalson-Tygielska, PIW.

/// Nouschi A. 2013. De Gaulle et la fin de la guerre d'Algérie, „Guerres mondiales et conflits contemporains", 2013/3 (nr 251), s. 163-170. 
/// Marcin Darmas - socjolog kultury i dziennikarz. Adiunkt w Instytucie Socjologii Uniwersytetu Warszawskiego. Opublikował wiele prac o literaturze Michela Houellebecqa, m.in. w „Odrze”, „Znaku” oraz „Rzeczpospolitej”. Wydał m.in. Obywatela rycerza. Zarys socjologii filmu, Wydawnictwa Uniwersytetu Warszawskiego, Jarzmo wielkości Francji (wraz z Agatonem Kozińskim), Wydawnictwo Akademickie „Dialog”, a ostatnio Na dystans. Roz̧ważania socjologiczne o boksie, Wydawnictwa Uniwersytetu Warszawskiego.

ORCID: https://orcid.org/0000-0001-7252-6720

E-mail: marcin.darmas@gmail.com 